Arq. Bras. Med. Vet. Zootec., v.56, n.6, p.796-798, 2004

\title{
Communication
}

(Comunicação)

\section{First report of Diphyllobothrium mansoni (Cestoda, Diphyllobothridae) infecting Cerdocyon thous (Mammalia, Canidae) in Brazil}

[Ocorrência de Diphyllobothrium mansoni (Cestoda, Diphyllobothridae) parasitando Cerdocyon thous (Mammalia, Canidae) no Brasil]

\author{
K.R. Santos ${ }^{1}$, L.S. Catenacci ${ }^{2}$, M.M. Pestelli ${ }^{2}$, R.K. Takahira ${ }^{3}$, R.J. Silva* ${ }^{4}$ \\ ${ }^{1}$ Estudante de Mestrado - Faculdade de Medicina Veterinária e Zootecnia- UNESP - Botucatu, SP \\ ${ }^{2}$ Estudante de Graduação - Faculdade de Medicina de Veterinária e Zootecnia- UNESP - Botucatu, SP \\ ${ }^{3}$ Faculdade de Medicina Veterinária e Zootecnia- UNESP - Botucatu, SP \\ ${ }^{4}$ Instituto de Biociências - UNESP \\ Distrito de Rubião Júnior \\ 18618-000 - Botucatu, SP
}

The species Cerdocyon thous (Mammalia, Canidae) has been reported as a host for Diphyllobothrium mansonoides (Schmidt, 1986). In contrast, the species $D$. mansoni has been described as a parasite of Felis domestica in Porto Rico (Cram, 1927), Canis familiaris in Korea (Cho et al., 1981), Felis catus in Chile (Torres e Figueroa, 1982), Bufo marinus in Australia (Speare, 1990), man in China (Cai, 1991), and pigs in the Platea District, Yunnan (Lan et al., 1995); however its occurrence has never been reported in Brazil.

The objective of the present study is to report the occurrence of $D$. mansoni infecting a $C$. thous, captured in Itatinga, State of São Paulo, Brazil (S $23^{\circ} 0606^{\prime} \mathrm{W} 48^{\circ} 3657^{\prime}$ ).

A young $C$. thous specimen was assisted in the Veterinary Hospital of the Faculdade de Medicina Veterinária e Zootecnia, Unesp, Botucatu, after being run over by a car in Itatinga City. No clinical changes that could be attributed to the D. mansoni infection were noted, since the animal was severely debilitated by the accident. Despite its condition, diarrhea was not observed during its internment.
A fecal sample was analyzed by a flotation test (Willis), in which cestode eggs were identified. The animal died and at necropsy a specimen was observed in the small intestine. The helminth was collected, put in a refrigerator overnight, and fixed in AFA solution after compression. Morphological and morphometric analyses were accomplished by a computerized analysis of an image system (Qwin Lite 2.5 - Leica).

The scolex was not found. The cestode presented strobila with a length of $19 \mathrm{~cm}$, gravidity proglottids with $1.5(1.3-1.7) \mathrm{mm}$ in length and $3.1(2.8-3.4) \mathrm{mm}$ width. The worm had a cirrus sac, vestibule or vulva, anterior and posterior coils uterus in the longitudinal median line of the proglottids. The vagina passed traversing from its vestibule in an approximately straight path in the median line, was thrown into lateral undulations of considerable amplitude. The uterus opened by a pore well separated from and posterior to the vagina, and presented a varying number of loops in the terminal heavy walled portion in an "S" shape. The eggs measured 130.5 (112-185) $\mu \mathrm{m}$ in length and 73.7 (66-94) $\mu \mathrm{m}$ in width (Figure 1).

Recebido para publicação em 19 de setembro de 2003

Recebido para publicação, após modificações, em 20 de outubro de 2003

*Corresponding author (autor para correspondência)

E-mail: reinaldo@ibb.unesp.br 


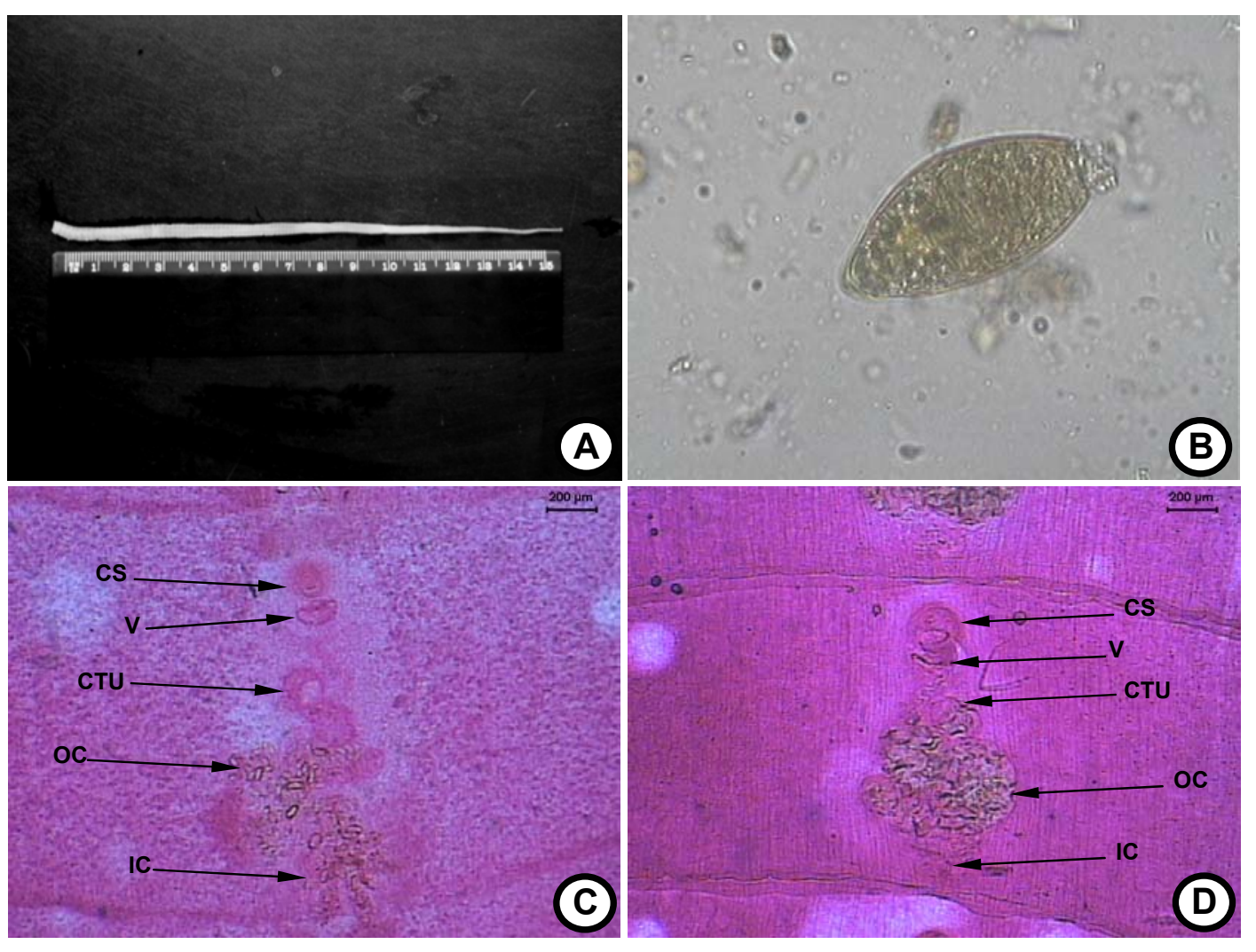

Figure 1. Diphyllobotrium mansoni (Cestoda, Diphyllobothridae) found in the intestine of Cerdocyon thous. A) general view of the strobila; B) eggs (magnification, 400x); C-D) proglottids: CS - cirrus sac, V - vagina, TCU - terminal chamber of the uterus, OC - outer coils of the uterus, IC - inner coils of the uterus.

These morphological data regarding the strobila and the characteristics of the eggs allowed us to conclude that the cestode species involved in the parasitism of the $C$. thous was D. mansoni. The uterus morphology of the reported species is similar to that described by Mueller (1936) and confirms the identification of $D$. mansoni. The occurrence of this cestode in $C$. thous represents the first report of this helminth parasitizing this host and the first notice of its occurrence in Brazil.

Keywords: Diphyllobothrium mansoni, Cestoda, Diphyllobothridae, Cerdocyon thous, Mammalia, Canidae.

\section{RESUMO}

O trabalho descreve a ocorrência de Diphyllobothrium mansoni (Cestoda, Diphyllobothridae) no intestino delgado de um exemplar de Cerdocyon thous (Mammalia, Canidae), proveniente da região de Itatinga, Estado de São Paulo, Brasil. Este é o primeiro relato da presença desse cestódeo em C. thous.

Palavras-chave: Diphyllobothrium mansoni, Cestoda, Diphyllobothridae, Cerdocyon thous, Mammalia, Canidae 


\section{REFERENCES}

CAI, L.X. A case of Spirometra mansoni infection. Chin. J. Parasitic. Dis. Control., v.4, p.294, 1991.

CHO, S.Y.; KONG, S.Y.; RYANG, Y.S. Helminthes infections in the small intestine of stray dogs in Ejungbu City, Kyungii Do, Korea. Korean J. Parasitol., v.19, p.56-59, 1981.

CRAM, E.B. Diphyllobothrium mansoni in Porto Rican cat. J. Parasitol., v.1, p.70, 1927.

LAN, G.X.; GAO, Y.B.; HE, W.F. et al. Preliminary investigation of Spirometra mansoni in pigs on the plateau of Lijang District, Yunnan. Chin. J. Vet. Med., v.21, p.23-24, 1995.

MUELLER, J.F. Comparative studies on certain species of Diphyllobothrium. J. Parasitol., v.22, p.471-478, 1936.

SCHMIDT, G.D. Handbook of tapeworm identification. Florida, Boca Raton, 1986. 675p.

SPEARE, R. A review of the diseases of the toad, Bufo marinus, with comments on biological control. Aust. Wildl. Res., v.17, p.387-410, 1990.

TORRES, P.; FIGUEROA, L. Infeccion por Spirometra mansoni (Cestoda, Pseudophyllidae) en el sur le Chile. Bol. Chil. Parasitol. v.37, p.72-73, 1982. 